\title{
Security Culture as a Precondition for Multiculturalism (in the Balkans)
}

\author{
Svetlana STANAREVIĆ, PhD \\ Faculty of Security Studies, University of Belgrade, RS \\ E-mail: svetlana_stanarevic@yahoo.com \\ Jasmina GAČIĆ, PhD \\ Faculty of Security Studies, University of Belgrade, RS
}

\begin{abstract}
Security culture, as a relatively new and still insufficiently developed concept within security studies, has a wide range of meanings and interpretations, allowing us to view the application of this concept in different socio-political and security contexts. Multiculturalism is another phenomenon that does not have a long history, although it is very important in the contemporary world and manifests itself in various fields such as politics, culture, economy, education and, of course, security. The cultural diversity of every modern society is multidimensional and includes not only biological/sex differences, culturally translated into gender differences, but also generational differences as well as the socially conditioned ones which concern national, religious and regional affiliation and membership in a language community.

One of the many interpretations and explanations of the concept of multiculturalism at the beginning of the $21^{\text {st }}$ century, particularly bearing in mind social practices, is that it poses a threat to security. Such a perspective on multiculturalism involves applying the concept of security culture in order to identify different forms of cultural pluralism, each of which can present a challenge with its specific characteristics, manifestations, and forms of (non-)acceptance by the wider social community.
\end{abstract}


Although societies and countries of the Balkans can be shown to be extremely multicultural, multiculturalism as a politico-ideological concept has not been given its rightful place in these very societies and countries. For that reason, in this paper we will try to show that development of security culture within different social subjects and institutions, such as educational, is a precondition for a better understanding of the contradictions and developmental prospects of multicultural societies (in the Balkans).

Keywords: security culture, multiculturalism, cultural pluralism, Balkans.

\section{Multiculturalism}

Multiculturalism is emerging as a possible response to the problem of multicultural reality of modern societies. This concept involves various forms of cultural pluralism, each of which can present some kind of challenge. The issues and challenges of multiculturalism and cultural diversity are increasingly becoming major talking points at global political forums and within academic circles. As a policy, philosophy or social and intellectual movement, multiculturalism refers to the acceptance of different cultures in a society and entails active support for these cultural differences by various groups. While multiculturalism is increasingly recommended as effective intervention at a social level, above all at a local level, it is a debatable and emotionally fraught term (Verkuyten, 2004). The problems and dilemmas surrounding multiculturalism are addressed, among others, by political scientists, (moral) philosophers and sociologists (Taylor 1992, Goldberg 1994, Kymlicka 1995, Favell 1998, Barry 2001, to name a few). Some of them highlight the positive sides of multiculturalism (this concept offers a solution for the management of cultural differences), while others focus on the negatives (it aggravates the causes of conflicts, incites separatism and jeopardises social unity and cohesion).

The most commonly held view is that a state is multicultural if its citizens either belong to different nations (multinational state) or have emigrated from different nations (polyethnic state) and if this fact represents a major aspect of personal identity and political life. Some authors, political officials and civil society representatives use the term "multicultural" in a broader sense, so that it encompasses a wide range of non-ethnic social groups which are, for different reasons, marginalised or excluded from 
the dominant social matrix. Others include enclaves, social movements and voluntary associations in the term (Kymlicka, 2004).

This diversity gives rise to a host of questions which can become points of contention in a state and society at a regional, national or local level. Establishment of regional autonomy, exercise of language rights, political representation, immigration policy and national symbols are only some of the issues that lead to conflict between national minorities and national majorities. The biggest challenge facing today's democratic countries, regardless of where they are in the world, is precisely how to resolve these problems in the most acceptable way.

If we were to go back in time and observe different historical periods and epochs, from the Roman Empire to the modern age, we would see that all the populations in these epochs were made up of linguistically, culturologically and religiously heterogeneous groups and that there was always the question of how to manage these different groups and negotiate their everyday practices and the interactions that surround them. The time of mass migrations in the second half of the $19^{\text {th }}$ century brought with it some new issues concerning diversity management, but expectations for assimilation, on one hand,and public rejection of social and cultural differences, on the other, were largely responsible for keeping the government in power in certain countries. The second half of the $20^{\text {th }}$ century is famous for the emergence of different civil rights movements, which called for, among other things, public measures for reducing discrimination, as well as different challenges facing social, political and public services that arose from the new wave of immigration. The period saw the adoption of policies, structures and programmes designed to tackle the new differences and integrate them into the existing social structure.

In order to respond to multiculturalism adequately different institutional initiatives were launched, opening up numerous possibilities such as group representation in local and national authorities, restructuring of public services, introduction of measures for the promotion of equality, respect and tolerance, especially the dominant population's tolerance of the minorities, and provision of funds to aid continuity of tradition and identity among immigrant groups (as opposed to assimilation). As Steven Vertovec states in his text, in many countries multiculturalism required actions in the following areas: 


\section{Seccurity}

- public recognition: supporting ethnic minority organisations, facilities and activities and creating public consultative bodies incorporating such organizations;

- education: often addressing dress, gender and other issues sensitive to the values of specific ethnic and religious minorities; creating curricula reflecting the backgrounds of ethnic minority pupils; offering mother tongue teaching and language support and establishing own schools (publicly financed or not);

- culturally sensitive practices, training and information established within social services and among healthcare providers, police and the law courts;

- public materials: providing public material (such as health promotion campaigns) in multiple languages;

- law: recognising cultural exceptions to laws (such as Sikh turbans instead of motorcycle helmets); permitting oaths on sacred books other than the Bible; recognising other marriage, divorce and inheritance traditions;

- protecting cultural practices from discrimination and incitement to hatred religious accommodation: permitting and supporting the establishment of places of worship, cemeteries and funerary rites; allowing time off work for worship;

- food: allowing ritual slaughter; providing proscribed foods (halal, kosher, vegetarian) in public institutions;

- Broadcasting and media: monitoring group images to ensure nondiscrimination or to avoid stereotypes; providing own media facilities for minority groups (Vertovec, 2010:84).

As we have already mentioned, developed, western societies (democracies) approach multiculturalism differently from the rest of the world, which is why this issue has been developed and accepted to varying degrees as a political and ideological concept. A recurrent dilemma in all societies is how to achieve, by means of democratic multiculturalism, a rich pluralist culture that includes society as a whole rather than have a mere assimilation of minority cultures. Balkan countries and societies find this issue/problem even harder to resolve, seeing as they have not even reached the appropriate degree of democracy, that is, of democratic and political culture. Another dilemma that stems from the discussion about multiculturalism and the failure of some ethnic communities to integrate into a majority society is whether that poses a threat 
to (national) security and how to strike the right balance between safeguarding cultural diversity and maintaining national cohesion in times of war or a state of emergency. In other words, is it possible to reach a compromise between multiculturalism and security and, furthermore, how can this be achieved in the Balkans? ${ }^{195}$

Namely, the Balkans is a region with an undefined and unstable political identity. Adding to this observation a new one - that one should renounce one's national identity and nationalism in order to embrace liberal, European and Western principles - only causes more frustration for all Balkan peoples. Most Balkan nations see themselves as peoples living at the crossroads where roads between Europe and Asia both converge and diverge. In addition to being the historic birthplace of numerous civilisations, the Balkans is also a zone characterised by ethnic heterogeneity, on one hand, and the meeting place of three major religions, i.e. Western Christianity, Eastern Christianity and Islam, on the other. This ethnic, religious and cultural heterogeneity is often cited as the main cause of conflicts, historical turmoil and interethnic wars, as well as an impediment to the region's complete self-identification and preservation of an established cultural identity. Under the influence of a dynamics determined by ethnic and religious heterogeneity, thus established identity of the entire region or individual peoples inhabiting it is subject to changes and internal transformations (Štrbac, 2007).

Lack of intercultural communication in the Balkans, which is a prerequisite for cultural convergence, is the result of interethnic relationships being burdened with past events, hostility and prejudice. Terms such as European "powder keg" and "balkanisation" were coined in late $19^{\text {th }}$ and early $20^{\text {th }}$ centuries to denote the events and relations between Balkan countries. Some authors identify culture as the trigger for hatred and wars in the Balkans, which was particularly evident in the 1990s. Today, those who support this view also claim that culture emerged almost intact from these

\footnotetext{
${ }^{195}$ This is not an easy question to answer not only in connection with the Balkans but more generally, especially when other categories are factored into the analysis. Namely, it is said that freedom is a key factor in security, and both are significant for multiculturalism. Everything, then, can be considered in terms of how much freedom, what kind of freedom, who should be given freedom, why and how freedom should be restricted, and who should have their freedom restricted, etc. in society and in the states that are rich in various cultural and national identities whose needs for an adequate degree of freedom is often in conflict with each other.
} 


\section{Seccurity}

wars and that it is ready, if the need arises, to once again serve the same purpose: to ignite (Stanarević, Dimitrijević, Milenković, 2013).

On the other hand, establishment of a multicultural public sphere in the Balkans seems impossible due to its heavy politicization which prevents minority rights emerging from the obscurity of intimacy and privacy. "Conflicts and war ideologies in the Balkans can only partly be explained by internal contradictions, as they almost always appear in tandem with interested political elites" (Milošević, 2007:13). Even when talking about the concept of public recognition of minority identities, that is, their protection by a special legal status, we can see how difficult it is to consider it outside the political framework.

This is because the state is not neutral about differences, and its institutions could be said to favour "some languages, majority cultural practices or national symbols, at the expense of others" (Pešić, Novaković, 2010:150). This is particularly pronounced in the process of creating a national state on the following principle: one nation, one language, one culture, one territory. The consequence of such a process in the Balkan region is domination of the social majority, that is, assimilation and lack of recognition of minority groups and their cultural identities. There is a huge gap between civil rights and national identity seeing as members of minority groups in the Balkans feel marginalised due to their different social and cultural identity, despite all the common citizenship rights they enjoy. For, as one of the founders of the concept of multiculturalism, Will Kymlicka, points out: "citizenship is not only a legal status, defined by a set of rights and responsibilities. It is also an identity, an expression of one's membership in a political community" (Kymlicka in: Pešić, Novaković, 2010:150).

The liberal model, according to which cultural minorities will be protected if basic civil and political rights are guaranteed to all individuals regardless of their social and cultural affiliation, has proved to be somewhat flawed in multicultural societies in the Balkans. Civil rights cannot be said to be ethically neutral, since cultural affiliation determines the outcome of political decisions and, as a result, the state is not "blind to differences" (Puzić, 2004). What is more, consciously or unconsciously it promotes some languages, cultural practices or national symbols while inevitably ignoring or suppressing others. However, such coexistence is hard to forge in the Balkans and, consequently, instead of finally working towards a "culture of peace", Balkan societies are once again engaging in ideological mobilization of the masses. So here we are, reproducing the discourse of "balkanization" all over again. 


\section{Seccurity}

\section{Security culture and multiculturalism}

Without wishing to delve deeper into all that multiculturalism is and is not, that is, into all of its manifestations and varieties observed, for example, in the USA, Canada, Australia or Great Britain, we would like to show how better to understand the many contradictions and development potential of multiculturalism and multicultural societies (for instance, in the Balkans). There have been numerous attempts to prevent cultural diversity in a society from becoming a serious threat, which can easily disrupt social relations. The concept of multiculturalism has revealed both its advantages and disadvantages in an attempt to solve the problems that may arise from cultural diversity. By developing different policies and programmes in political, social, educational or other spheres, this concept managed to partially solve some problems while creating new ones. In response to the threats of terrorism and political violence or the big wave of migrations in recent years, security has come into a sharper focus, coinciding with the attack on multiculturalism and the suitability of multiculturalist policy.

For this very reason, we have come increasingly to perceive multiculturalism as a challenge, as an ideological and political response which creates problems, disrupts unity or the form of community achieved in a society. In the wave of migrations sweeping Europe in recent years, there is more and more talk about securitization of migrations and, by extension, of multiculturalism. In a bid to determine whether it is appropriate to securitize migrations and, by extension, multiculturalism, we must look for those concepts and practices that will provide a suitable solution for situations in which it is (il) legitimate to talk about securitization and representation of migrations and multiculturalism as security problems, as well as for the factors that can be necessary prerequisites for a proper understanding of these phenomena. It seems to us that security culture is one of those factors.

From a modern standpoint, security culture refers to the way in which certain ideas about the security system and structure are developed, as well as about what is perceived as a danger to our lives or a threat to our values, and is at the same time our most obvious defence against them. It is a factor in shaping what is invaluable or important and it regulates our moral, security, economic and political priorities (Stanarević, 2012). In addition to defining the possibilities and limitations of what is considered important, valuable or not valuable, security culture determines what does 


\section{Seccurity}

and does not deserve protection and how to go about providing it. We have already stated that Balkan peoples lack democratic and political cultures or, more precisely, a full manifestation of these cultures, but before these cultural forms are fully developed, it might be more worthwhile to develop a security culture.

Security culture is also manifested in the way we understand the environment in the broadest sense, show an understanding for the dynamic of social relations (both at an individual and general level, between different social groups, different cultures, etc.), perceive the importance of absolute control over one's own goods (the principle of sovereignty) as well as in the way in which we perceive and define dangers and/or threats, determine interests and choose means or instruments of action (Stanarević, 2012).

It is a well-known fact that culture, as a collective heritage, offers guidelines to its members and produces a wealth of ideas and practices, rules and norms which indicate what is right and what is wrong. Also, culture shapes the lives of its members, not only as individuals but also collectively. Like traditional culture, security culture selects values, in this case those which are relevant to survival (of an individual or community) and which should assume a leading role in society, particularly when the values of different groups are in conflict or threaten to provoke conflict (Stanarević, Gačić, 2014).

In that case, there are many possibilities and many values to be chosen, even when they are not necessarily key to survival but are only a token of respect for some human or minority rights. So, for example, if we must choose between freedom and security, or between freedom, security and multiculturalism, we need to introduce some principles that will help us more easily to resolve potential contradictions which arise from favouring one of the aforementioned values. In his text The Challenges of Multiculturalism, the author Malory Nye discusses the principle of recognising and acknowledging diversity, the study of differences - a multicultural society is unstable if it is based on the isolation of certain groups and the different groups' unfamiliarity with each other - the principle of tolerance and understanding, as well as the strengthening of general shared identity which goes beyond but at the same encompasses singularities (Nye, 2007). The European Union and the Council of Europe advocate an alternative to multiculturalism - intercultural dialogue - and it is the above principles that these institutions promote in the process of establishing new frameworks of soft 


\section{Seccurity}

policy measures as support to strategies for opening dialogue between different cultural groups in a society ${ }^{196}$.

The European Union also defines standards with which the legal systems of all new member states must be aligned. Minorities are a major issue as far as organization of political, cultural and economic life is concerned, rather than a lesser phenomenon which can solved by technical means. Tackling the issue of minorities on legal bases is aimed at integrating minorities into society - into its political, economic, cultural and other forms and institutions. This would help avoid assimilation and ghettoization, and harmonise the relations and cooperation between the majority and all the minorities in keeping with the principles of the rule of law and the democratic social system. Difficulties arise out of the vast differences in the economic position, the infrastructure of the education network and the level of education of some minorities, as well as in their material and human resources. Difficulties are also due to the failure of the national education system to adequately deal with these issues. Even when laws and regulations are in place, their enforcement lacks appropriate activities and results.

Since the modern world is full of contradictions, the inevitable question is how and to what extent education can help avoid conflict and develop awareness of "the other" and of the interdependence, challenges, risks and threats which put a strain on everyday life and which will encourage people to face them and respond appropriately; also, it can help inspire people to cooperate. Level of education, quality of education and academic achievements all have an impact on how a person treats themselves, other people, members of different ethnic groups, mankind (Irvine, 2003). For this reason it is very important how curriculums and syllabuses are designed and developed at all the levels of the national education system, what personnel should be trained to pass on knowledge, and how and under what circumstances knowledge is passed on.

Unified national education programmes must be created so as to promote values which are important for a future shared life and ideas which will bring stability and, above all, security for the entire community; furthermore, they must fulfil conditions that involve traditional values connected with the life of all the groups living

\footnotetext{
196 In 2008, at the Council of Europe Ministers of Foreign Affairs $118^{\text {th }}$ Ministerial Session, the White Paper on Intercultural Dialogue was adopted, and it was presented as a model for cultural diversity management aimed at future. The basic idea of this concept is "Living Together as Equals in Dignity". (White Paper, 2008). Dimitrijević, Branko, ed. Bela knjiga o interkulturnom dijalogu "Živimo jednaki u dostojanstvu". Beograd. Ministarstvo kulture Republike Srbije 2009.
} 
in this space, appeal to all social strata, respond to challenges responsibly and appeal to neighbouring countries, with which they primarily cooperate and develop goodneighbourly relations. This further implies that multiculturalism is understood not only as cultural diversity but also as a need to ensure equality as well as other components such as social equality and inclusion (Berry, 2012).

Ideas about culturally responsive teaching, multi-cultural education and the like are already established in the literature and the education programmes of many countries. As the author Geneva Gay stated back in 1972:

"Education must be specifically designed to perpetuate and enrich the culture of a people and equip them with the tools to become functional participants in society, if they so choose. This education cannot progress smoothly unless it is based upon and proceeds from the cultural perspectives of the group of people for whom it is designed. Since all Americans do not have the same set of beliefs, attitudes, customs, values, and norms, a single system of education seems impossible to serve everyone.... [Educators] must accept the existence of cultural pluralism in this country and respect differences without equating them with inferiorities or tolerating them with an air of condescension" (Gay, 1972: 35).

Or expanded on her views in 2010:

"Culturally responsive teaching is the behavioural expressions of knowledge, beliefs, and values that recognize the importance of racial and cultural diversity in learning. It is contingent on ... seeing cultural differences as assets; creating caring learning communities where culturally different individuals and heritages are valued; using cultural knowledge of ethnically diverse cultures, families, and communities to guide curriculum development, classroom climates, instructional strategies, and relationships with students; challenging racial and cultural stereotypes, prejudices, racism, and other forms of intolerance, injustice, and oppression; being change agents for social justice and academic equity; mediating power imbalances in classrooms based on race, culture, ethnicity, and class; and accepting cultural responsiveness as endemic to educational effectiveness in all areas of learning for students from all ethnic groups" (Gay, 2010:31). 
While it may be common knowledge, it bears repeating that education is charged with tasks of a wider social importance - to guide people and instil in them human rights, aesthetic, moral, ethnic, national, cultural and universal humanistic values, and teach them to understand the necessity of international cooperation and preservation of world peace and security as the prerequisites for human existence. In modern society, increasing importance is attached to education not least because of the ever-growing complexity of all forms of life and the introduction of high technologies, which also carry with them certain security risks. In that sense, raising the level of security culture through a national education system is instrumental in saving the human community from (self-) destruction, in which process the power of the human intellect and culture is relied upon the most.

Namely, let us recall a definition given by Ljubomir Stajić, who says that

"security culture is a set of accepted attitudes, knowledge, skills and rules from the field of security, manifesting themselves as behaviour and process, about the necessity, ways and means of protecting personal, social and international values from all sources, forms and agents of threat, regardless of the time or place of their realisation" (Stajić, 2013).

If we lay emphasis on knowledge, considering the context in which Stajic provided his definition, then it refers to theoretical, practical, professional and personal knowledge (learning) that helps to identify correctly and explain the phenomenon of threats as well as the knowledge that serves to remove and suppress or, at the very least, mitigate them. This kind of knowledge is acquired through education in the field of security and other social, technical or natural disciplines.

Security culture as a body of knowledge can be represented and examined through a modern, humanistically conceived curriculum which is meant to offer a possibility of creating a general sociocultural climate conducive to the exercise and respect of basic human rights, non-violent behaviour and development of soft skills and hard skills for the application of these principles in day-to-day life. The concept of security culture looks at the factors which fall within the scope of analysis, contributing to greater security, and at the socio-political and economic relations which are most likely to generate maximum security for individuals, groups, nations-states and the world as a whole. Furthermore, it is necessary to develop the ability to understand and respect the role of culture and its influence on politics, strategy and security, this being a key skill of security thinking. Cultural knowledge involves the capacity to examine 


\section{Seccurity}

history, values, ideology, politics, religion and cultural and other dimensions, as well as to assess their potential impact on security policy. It is worth pointing out that not only knowledge about security and security phenomena (as stated in some definitions) but also cultural knowledge, if only as a context in which a security phenomenon takes place, are significant for the development of new perspectives on security culture. One of the new perspectives is multiculturalism, that is, multicultural societies and environments which experience some kind of security issue that needs to be understood, explained and resolved taking into account the different cultural practices, cultural patterns, and traditional, religious or ethical systems of the social groups living in that space.

Unlike traditional curriculums, which essentially entailed students learning the content of a syllabus by rote, modern curriculums are aimed not only at developing critical thinking, research skills and problem-solving skills in students, but also at enabling them to make decisions that are important for leading a successful life in a fast-changing society which is going through crisis cycles and in which the acquired knowledge fast becomes obsolete. In other words, what we need is knowledge about constructive human behaviour and skills which can be used to prevent the harmful consequences of fast changes for every individual, social group and society as a whole. These skills derive from knowledge about gender equality and human rights principles and non-violence as well as from the ideas about why and how these principles should be upheld, elaborated and applied in practice. These principles should be discussed with all the actors in the educational process (both the formal and informal dimension) in the context of the characteristics of these actors, their immediate and broader social environment, dominant religion and cultural traditions.

All the above can once again be confirmed by the views expressed by Geneva Gay, who argues that culturally responsive teaching

"simultaneously develops, along with academic achievement, social consciousness and critique; cultural affirmation, competence, and exchange; . . . individual self-worth and abilities; and an ethic of caring. It uses [different] ways of knowing, understanding, and representing various ethnic and cultural groups in teaching academic subjects, processes, and skills. It cultivates cooperation, collaboration, reciprocity, and mutual responsibility for learning among students, and between students and teachers. It incorporates high-status, cultural knowledge about different ethnic groups in all subjects and skills taught. . . . Thus, [it] validates, 


\section{Seccurity}

facilitates, liberates, and empowers ethnically diverse students by . . cultivating their cultural integrity, individual abilities, and academic success." (Gay, 2010: 45-46).

In addition to the foregoing, all the experiences, ideas and issues that appear in the meantime should be analysed, directed and encouraged in such a way as to foster the development and dissemination of security culture as a new manifestation of the knowledge that should contribute to survival, development and well-being. This must also entail measures for greater equity in access to education (at all levels) of all social strata, greater education coverage, greater efficiency and access to education, and, of course, curriculums and syllabuses suited to future needs and tailored to the needs of different groups.

The development and application of the concept of security culture based on education involves transmitting and cultivating knowledge, abilities and specialised skills, forming opinions and broadening the horizons of individuality. Like other social institutions, formal institutions in the field of education and upbringing have manifest and latent functions. Manifest functions include, for example: teaching and learning (foreign) languages, mathematics and natural sciences, and knowledge from the fields of economy, geography, history and law. Latent functions include cultural codes, maintenance of social control and social hierarchy, and promotion of social integration, all of which are instrumental in supporting multiculturalism.

As cited in the literature that deals with this problem matter, there is an ongoing historical attempt to construct a new set of educational practices in response to turmoil and violence and, by extension, to security concerns. In this context, the idea of the individual subject, which was the object of much calculation in a material context, was also part of a related series of practical transformations, an attempt to rearticulate both identity and epistemology in the service of new social practices which lead to peace and civil order.

We live in a time of innovations and breakthroughs in the very techniques for conducting culturological research into matters of peace and security. Educational institutions, particularly institutions of higher education, need to be part of a wider surge of interest in cultural research as well as issues of conflict and other security problems. Major advances in the overcoming of cultural barriers concerning the challenges of global governance can be made if a range of changes are implemented, from cultural education to culturological research, as well as in situational drafts and local actions. This must be done with dedication, expertise and creative exploitation of 
available resources and demonstrated through modelling, simulation, experiments and various forms of play. In other words - new problems, new parameters, new measures, new models and, finally, new approaches to developing and applying security culture. The acquired knowledge and skills must be applicable and usable in economic and practical life. They represent the wealth of all the members of a community and, as a shared value, serve the interests of the entire community.

\section{Conclusion}

Just like in the distant past, the modern state also tries to exert powerful centralising forces in order to achieve cultural homogeneity, which essentially equates unity with homogeneity and equality with uniformity. However, modern multicultural societies are a unique historical phenomenon which opens up new questions and calls for new concepts for a better understanding of its contradictions and development perspectives. The notion of multiculturalism is one of these concepts, and it is often explained as a political and social response to a social situation where there is no longer a consensus on a unified national culture which is meant to integrate a multicultural society.

However, despite people's hopes, multiculturalism has not produced a unified community in which groups with different cultures and traditions live together in harmony. It has been shown to cause segregation and lead to the division of communities with very little solidarity between groups. If not properly governed, it can eventually become a threat to security and stability within states, as well as within the international system. This is why we have tried to point out the importance of security culture as a precondition for a successful multicultural society, i.e. multiculturalism, which is supposed to be a valid political response to the challenges of globalisation, migration and other modern security challenges. 


\section{References:}

1. Barry, B. (2001), Culture and Equality, Cambridge: Polity;

2. Berry, J. W. (2012). Intercultural Relations in Plural Societies: A Comparative Perspective. In A. Assaad, E. Bribosia, A.Rea, \& I. Rorive (Eds.), The Contribution of Diversity to Social Cohesion. Leiden, The Netherlands: Brill Martinus Nijhoff;

3. Dimitrijević, Branko, ed.(2009) Bela knjiga o interkulturnom dijalogu "Živimo jednaki u dostojanstvu", Ministarstvo kulture Republike Srbije, Beograd;

4. Favell, A. (1998) Philosophies of Integration: Immigration and the Idea of Citizenship in France and Britain. London: Macmillan;

5. Gay, G. (1972). Coloring with Black or Brown is not enough. Texas Outlook, 56(1), (34-35);

6. Gay, G. (2010). Culturally responsive teaching: Theory, research, and practice (2nd ed.). New York: Teachers College Press;

7. Goldberg, D.Th., ed. (1994) Multiculturalism: A Critical Reader. Oxford: Blackwell;

8. Irvine, J. J. (2003). Educating teachers for a diverse society: Seeing with the cultural eye. New York, NY: Teachers College Press;

9. Kymlicka, W. (1995) Multicultural Citizenship. Oxford: Clarendon;

10. Кимлика, Вил, (2004), Мултикултурализам - мултикултурно грађанство, цИД, Подгорица, и Јесенски и Турк, Загреб;

11. Malory Nye, (2007) "The Challenges of Multiculturalism", Culture and Religion, An Interdisciplinary Journal, Vol.8, No. 2;

12. Милошевић, Б. (2007). Социокултурни процеси на Балкану: од идеологије рата до културе мира, Социолошка пуча, I/2, Филозофски факултет, Нови Сад;

13. Puzić, S. (2004) Multikulturalizam i izazovi posttradicionalne pluralizacije. Politička misao, vol. XLI, br. 4, (str. 59-65);

14. Stanarević, S. (2012), Koncept bezbednosne kulture i pretpostavke njegovog razvoja, doktorska disertacija, Fakultet bezbednosti, Univerzitet u Beogradu;

15. Stajić, Lj., Mijalković S., Stanarević, S. (2013), Bezbednosna kultura, III dopunjeno izdanje, Pravni fakultet Univerzitet u Novom Sadu; 
16. Stanarević, S., Gačić, J. (2014), "Culture as National Security Interest", Contemporary Macedonian Defense, Ministry of Defence Republic of Macedonia, Vol.14, Number 26, Skopje;

17. Stanarević, S., Dimitrijević, I., \& Milenković, M. (2013). Culture and Cultural Differences as a Security Challenge or a Context for Dialogue. In: Mojanoski, C. (Ed.) (2013). The Balkans between Past and the Future: Security, Conflict Resolution, and Euro-Atlantic Integration, Vol. 2 (pp. 213-232). Skopje: Faculty of Security;

18. Štrbac, Lorna. (2007), Globalizacija i nacionalna kultura,Kulturno obrazovani centar, Šid;

19. Taylor, C. (1992), Multiculturalism and the Politics of Recognition, Princeton, NJ: University of Princeton Press;

20. Verkuyten, Maykel (2004), "Everyday ways of thinking about multiculturalism", Ethnicities, SAGE Publications, (pp. 53-74). 